\title{
Grikių grūdų užterštumas mikroskopiniais grybais ir mikotoksinais
}

Ilona Kerienè,

Audronė Mankevičienė,

Rūta Česnulevičienè,

Eugenija Bakšienė

Lietuvos agrarinių ir mišku mokslų centras, Instituto al. 1,

LT-58344 Akademija, Kédainiu r.

El.paštas: ilona.keriene@gmail.com;

audre@lzi.lt; perloja@perloja.lzi.lt;

eugenija.baksiene@voke.lzi.lt
2011-2013 m. Lietuvos agrarinių ir miškų mokslų centre (LAMMC) atlikti tyrimai, kurių tikslas - nustatyti grikių grūdų užterštumą mikroskopiniais grybais ir jų sintetinamais mikotoksinais. Mèginiai analizèms surinkti iš LAMMC Vokès filialo bei Perlojos bandymų stoties ekologiškai ir ịprastai augintų grikių pasèlių. Mikotoksinai grūduose buvo nustatyti imunofermentiniu (ELISA) ir efektyviosios skysčiu chromatografijos (ESCh) metodais. Rezultatai parodè, kad grikių grūdų užterštumas Fusarium genties grybais skirtingais tyrimų metais sieke 11-58,5\%. Didžiausią dali sudarè F. avenaceum, F. sporotrichioides, F. equiseti, F. poae, F. semitectum, F. graminearum ir kt. Fusarium spp. rūšiu sudètis bei analizuotų mikotoksinų koncentracijos skirtingais tyrimų metais buvo nevienodos.

Po 7 menesių sandèliavimo ant grikių grūdų buvo aptikti Mucor, Rhizopus, Aspergillus, Penicillium genčiu grybai. Tai rodo, kad šiais grybais grikių grūdai galèjo užsiteršti sandèliuojant. Nevalytuose grikių grūduose aflatoksino $B_{1}$ $\left(\mathrm{AFL}_{1}\right)$ padidejo dvigubai, ochratoksino $\mathrm{A}(\mathrm{OCH} \mathrm{A})-22 \%$. Nustatyta didžiausia grikių mikotoksikologinè tarša $2011 \mathrm{~m}$., nes $78 \%$ grikių mėginių buvo užteršti trimis toksinais - deoksinivalenoliu (DON), AFL $\mathrm{B}_{1}$ ir OCH A bei $22 \%$ méginiu keturiais toksinais - DON, AFL $\mathrm{B}_{1}$, OCH A ir zearalenonu (ZEA).

Raktažodžiai: grikiai, mikotoksinai, užterštumas, mikroskopiniai grybai

\section{IVADAS}

Grikiai (Fagopyrum esculentum Moench) pasaulinejje sveikų maisto produktų rinkoje vertinami kaip dietinis produktas, nes juose gausu maistinių medžiagų, mineralų, vitaminų bei biologiškai aktyvių junginių: $55 \%$ krakmolo, $12 \%$ baltymų, $4 \%$ riebalų, $2 \%$ tirpių karbohidratų, $7 \%$ ląstelienos, $18 \%$ sudaro kiti komponentai - organinès rūgštys, fenoliniai junginiai, taninai ir kt. (Amarowicz, Fornal, 1987; Krkošková, Mrázova, 2004; Vojtíšková et al., 2012). Palyginti su javais, mūsų šalyje mažai auginama grikių, daugiausia Pietrytinèje Lietuvoje, tačiau Žemès ùkio informacijos ir verslo duomenimis (2013), pastaraisiais metais grikių plotai didèja, $2013 \mathrm{~m}$. užsèta daugiau nei 30 tūkst. hektarų. Lietuvoje auginami grikiai, kurių veislès išvestos Ukrainoje, Baltarusijoje, pastaruoju metu populiarèja lietuviška ankstyva, žemaūgè veislè 'VB Vokiai'.
Grikiai unikalūs tuo, kad jų šaknų masė 2,515 kartų mažesnè nei miglinių augalų, tačiau vis tiek pralenkia siurbiamaja galia - išskirdami skruzdžių, acto, limoneno rūgští, geba pasisavinti dirvoje sunkiai tirpstančius fosforo rūgšties junginius, todèl grikiai priskiriami prie mažai reiklių dirvai, bet reiklių šilumai ir drègmei augalų (Zakarackas, 1999). Grikiuose gausu bioaktyvių junginių, pasižyminčių antimikrobiniu ir antigrybiniu poveikiu (Čabarkapa, 2008; Mošovska, 2012). Nors grikiai rečiau nei kiti augalai nukenčia nuo ligų, tačiau tyrimai rodo, kad gali būti pažeidžiami mikroskopinių grybų ir jų sintetinamų mikotoksinų (Llewellyn et al., 1988; Brindzova et al., 2009; Mošovská, Bírošová, 2012). Jau ankstyvosios brandos metu ant sèklų pasirodo pirmieji Fusarium spp. bei kitu grybų (Cladosporium spp., Botrytis spp., Alternaria spp.) taršos židiniai, kurie patenka iš dirvožemio bei nuo augalinių liekanų. Po derliaus nuemimo bei sandèliuojant mikroskopinių grybų sudètis keičiasi, grikių maistinę 
vertę taip pat mažina Aspergillus, Penicillium, Rhizopus, Mucor genčiu grybai (Shapira, 2004; Lugauskas, 2006; Krysińska-Traczyk et al., 2007; Pszczółkowska et al., 2011).

Potencialūs toksinių metabolitų gamintojai yra Fusarium, Aspergillus, Penicillium, Alternaria genčių grybai. Lietuvoje ypač kreipiamas demesys $\mathfrak{i}$ Fusarium genties mikroskopinius grybus - šviežiai nukultame derliuje fuzariozès pažeistų grikių kiekis neturi viršyti 1 \% (Juodeikienè, 2012). Ju produkuojami termiškai atsparūs, stabilūs rūgštinèje ir neutralioje terpejje mikotoksinai - zearelanonas (ZEA), deoksinivalenolis (DON), T2/ HT2 toksinas, fumonizinas (FUM) ir kt. sukelia hormoninius, reprodukcinius, kraujo apytakos, virškinamojo trakto, genetinius pakitimus bei mirtinas žmonèms ir gyvūnams mikotoksikozes (Diaz, 2005; Pateson, Lima, 2010). Kontroliuoti mikotoksinų sintezę yra sunku, nes keletas mikroskopinių grybų gali sintetinti tuos pačius bei skirtingus mikotoksinus, priklausomai nuo aplinkos sąlygų. Optimalios sąlygos užteršti produkciją iš karto keliais mikotoksinais yra palankios, kai temperatūra svyruoja tarp 15 ir $30^{\circ} \mathrm{C}$, o santykinis oro drègnis - apie $80 \%$ (Shapira, 2004). Penicilium spp. ir Aspergillus spp. sintetinami ochratoksinai pasižymi neuropatologiniu poveikiu, slopina baltymų sintezę, žmonèms sukelia „Balkanų endeminę nefropatiją " mirtiną lètinę inkstų ligą (BEN). Maisto kontrolès institucijos skiria didelị dèmesị ochratoksino A ( $\mathrm{OCH} \mathrm{A})$ kontrolei. Yra nustatytos didžiausios leidžiamos koncentracijos (DLK) pašaruose ir maisto produktuose: neapdirbtuose grūduose $-5,0 \mu \mathrm{g} \mathrm{kg}^{-1}$, maistiniuose

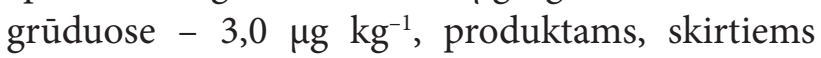
kūdikių ir vaikų mitybai, nustatytos griežtesnès normos - 0,5 $\mu \mathrm{g} \mathrm{kg}^{-1}$. 2008-2009 m. Europos Sąjungoje daugiausia problemų kèle iš trečiųjų šalių importuojami maisto produktai (Komisijos reglamentas (EB) Nr. 1881/2006). Toksiškiausiais laikomi Aspergillus genties grybų sintetinami aflatoksinai $B_{1}, M_{1}$, kurie veikia visus pagrindinius žmonių ir gyvūnų fiziologinius procesus. Europos Komisijos reglamentas numato ívairias prevencines priemones bei reglamentuoja šių mikotoksinų kiekius augalinèse žaliavose, ypač kūdikiams ir mažiems vaikams skirtuose grūdiniuose produktuose. Grikių žaliavai ir iš jų pagamintiems maisto produktams privaloma tik aflatoksino (AFL) kontrole, kurio bendras kiekis neturi viršyti $4 \mu \mathrm{g} \mathrm{kg}{ }^{-1}$, o AFL $B_{1}$ didžiausia leistina koncentracija apribota iki $2 \mu \mathrm{g} \mathrm{kg}{ }^{-1}$. Kūdikiams ir mažiems vaikams skirtuose produktuose mineto mikotoksino koncentracija neturi viršyti $0,1 \mu \mathrm{g} \mathrm{\textrm {kg } ^ { - 1 }}$. Kadangi DON koncentracijos kūdikių ir vaikų maiste negali būti didesnès nei $200 \mu \mathrm{g} \mathrm{kg}^{-1}$, ZEA - $20 \mu \mathrm{g} \mathrm{kg}^{-1}$, FUM - $200 \mu \mathrm{g} \mathrm{kg}^{-1}$, OCH A - 0,5 $\mu \mathrm{g} \mathrm{kg}^{-1}$, o juos produkuojančių grybų pasitaiko gana dažnai (Matić et al., 2009; Pszczolkowska et al., 2011), šiu mikotoksinų kontrolè yra labai svarbi. Kol kas diskusijos vyksta dèl T2 ir HT2 toksinų ribiniu verčiu iteisinimo (Komisijos reglamentas (EB) Nr. 1881/2006).

Fragmentinès informacijos apie grikių grūdų užteršimą mikroskopiniais grybais ir mikotoksinais yra, tačiau nepakankamai, kad padètų moksliškai įvertinti riziką, todèl šio eksperimento tikslas - nustatyti 2011-2013 m. derliaus grikių grūdų užterštumą mikroskopiniais grybais ir jų sintetinamais mikotoksinais.

\section{TYRIMŲ METODAI IR SĄLYGOS}

Sëjamųjų grikių grūdų mėginiai 2011-2013 m. surinkti po derliaus nuemimo iš LAMMC Vokès filialo bei Perlojos bandymų stoties ekologiškai ir íprastai augintu grikių pasèlių. Iprastai augintu grikių pasèliai pavasarị buvo patręšti NPK trąšomis. Derlius nukultas, kai subrendo daugiau nei 80 \% grūdų. Atliktos 'VB Vokiai', 'Smuglianka' ir 'Vlada' veislių analizès. Grikių grūdai (12\% drègnio) laikyti 7 ménesius nuo aplinkos sąlygų priklausančiame sandèlyje. Taip pat atliktos išvalytu ir neišvalytų grikių grūdų mėginių ochratoksino A $(\mathrm{OCH} A)$ bei aflatoksino $\mathrm{B}_{1}\left(\mathrm{AFL}_{1}\right)$ analizès.

Mikotoksinų plitimo priežastims įvertinti atlikti grūdų užterštumo Fusarium ir kt. grybais tyrimai. Vidinių grūdo audinių pažeidimas mikroskopiniais grybais nustatytas agarizuotų mitybinių terpių metodu (Mathur, Kongsdal, 2003). Sterili bulviu dekstrozès agaro (BDA) terpe su Tritono-X prie$\mathrm{du}(0,8 \mathrm{ml})$ buvo išpilstyta i sterilias Petri lèkšteles. Grūdai 5 min. dezinfekuoti $1 \%$ natrio hipochlorito $(\mathrm{NaOCl})$ tirpalu, nuskalauti steriliame vandenyje, nusausinti ant sterilaus filtrinio popieriaus ir išdèlioti Petri lèkštelèse (po 10 grūdų kiekvienoje) ant terpès paviršiaus. Tirta 400 grūdų iš kiekvieno tyrimo varianto. Grybai identifikuoti po 7-14 paru laikant $22 \pm 2{ }^{\circ} \mathrm{C}$ temperatūroje. Mikroskopinių grybų pažeistų grūdų skaičius ịvertintas 
procentais nuo bendro tirtų grūdų kiekio. Kolonijos, suformavusios rūšiai būdingus požymius, buvo identifikuotos remiantis P. E. Nelson ir kt., (1983) bei J. F. Leslie, B. A. Summerell (2006) apibūdinimais.

Mikroskopinių grybų, sudarančių kolonijas, skaičius ( $\mathrm{Ksv} \mathrm{g}^{-1}$ ) viename grame sèklų nustatytas pagal LST EN ISO 7218:2007. Grybų gentys identifikuotos remiantis P. E. Nelson ir kt., (1983), J. F. Leslie, B. A. Summerell, (2006), D. Satton ir kt. (2001) mokslininkų apibūdinimais.

Mikotoksinai grūduose nustatyti imunofermentiniu (ELISA) ir efektyviosios skysčių chromatografijos (ESCh) metodais. ELISA metodu nustatant toksinus naudoti skirtingi diagnostiniai testai: Veratox $^{\circledast}$ for DON 5/5 - 8331NE, Veratox ${ }^{\oplus}$ for zearalenone -8110 ir Veratox ${ }^{\circledR}$ for T2/HT2 - 8210, pagaminti Neogen corporation, Food Safety Diagnostics, Ayr, (UK), ịvertinti ochratoksiną A $(\mathrm{OCH} A)$, o aflatoksiną $\mathrm{B}_{1}\left(\mathrm{AFL} \mathrm{B}_{1}\right.$ ) taikyti Ridascreen $^{\oplus}$ (R-Biopharm AG, Vokietija) diagnostiniai nustatymo testai. Mėginių paruošimas kiekvienam mikotoksinui atliktas remiantis gamintoju rekomenduojamomis metodikomis (Neogen corporation, Food Safety Diagnostics, Ayr, UK). Nuskaityti rezultatus naudotas fotometras Multiskan MS su $650 \mathrm{~nm}$ ir 450 šviesos filtrais, rezultatai apdoroti - kompiuterinè programa Ascent Software.

ESChM taikytas nustatyti DON grikių grūduose (LST EN 15891:2010), mèginio gryninimui naudojant imuninio giminingumo kolonèlę (NeoColumn for DON, Neogen Europe Ltd. Ayr, UK) bei ultravioletinės šviesos detektorių. Kalibracinė kreivẻ sudaryta iš septynių standartinių DON tirpalų (koncentracijų intervalas $\left.0,092-5,86 \mu \mathrm{g} \mathrm{ml}^{-1}, \mathrm{R}^{2}=0,9999\right)$.

Rezultatų statistinè analizè. Duomenų kiekybinis vertinimas atliktas taikant statistinių duomenų apdorojimo paketą SELEKCIJA, naudojant vieno veiksnio dispersinès analizès ANOVA, STAT ENG programos metodą bei multifunkcini Dunkano kriterijų, kai p < 0,05 (Tarakanovas, Raudonius, 2003). Taip pat taikyta Microsoft Office Excel duomenų apdorojimo programa.

Meteorologinès sąlygos. $2011 \mathrm{~m}$. meteorologinès sąlygos grikiams augti buvo vidutiniškai palankios. Birželio mèn. I pusẻje vyravo aukšta temperatūra $-28-30{ }^{\circ} \mathrm{C}$, naktimis siekè iki $20^{\circ} \mathrm{C}$. Liepos mèn. kai kuriomis dienomis oro temperatūra pakildavo iki $28^{\circ} \mathrm{C}$, vidutinè temperatūra buvo apie $18^{\circ} \mathrm{C}$ (vidutinè daugiamete $-16,7^{\circ} \mathrm{C}$ ). Lijo dažnai, kritulių ménesio norma siekè 63-75 mm. Susiklostè labai palankios sąlygos plisti grybinèms ligoms. Rugpjūtị oro temperatūra buvo artima vidutinei daugiametei.

$2012 \mathrm{~m}$. pavasaris buvo drègnas. Sèti grikius ir jiems dygti sąlygos buvo palankios. Birželio, liepos mèn. buvo drègni ir šilti, rugpjūtis - taip pat drègnas, o rugsèjis - palyginti sausas. Grikių derliaus nuėmimas užsitęsė, nes rugsẻjo mèn. po drègno rugpjūčio buvo dar kuliami kiti javai.

2013 m. pavasaris labai vẻlavo. Atšilo tik ịpusejjus gegužès mèn. Mènesio pradžia buvo sausa, stipriai palijo tik paskutinèmis jo dienomis, dèl drègnų dirvų kelias dienas vèlavo grikių sèja. Grikių žydejjimo tarpsniu buvo sausa, augalai dienos metu vyto, atsigaudavo tik nakti. Grikiai subrendo vienodai ir palyginti anksti, rugsejjo mén. viduryje buvo nuimtas jų derlius.

\section{TYRIMŲ REZULTATAI IR JŲ APTARIMAS}

Nustatyta, kad 2011 m. grikių grūdai po derliaus nuèmimo buvo užteršti Cladosporium, Alternaria, Colletotrichum, Penicillium, Fusarium ir kt. genčiu grybais (1 lentelè).

Po 7 mènesius trukusio sandèliavimo dominuojanti grybų rūšinè sudètis nekito, tačiau atsirado grūdų, užterštų Mucor, Rhizopus, Aspergillus genčiu grybais, padidejjo užterštumas Penicillium spp. grybais. Tikètina, kad šie grybai pateko iš sandèliavimo aplinkos. Sandèliuotų grikių grūdų užterštumas mikroskopiniais grybais buvo $23 \%$ didesnis nei po derliaus nuemimo.

2011 m. grikiu grūdų mėginiuose po derliaus nuèmimo atlikus DON analizes nustatyta, kad visi méginiai buvo užteršti $100 \%$ (2 lentelè). Vidutinè DON koncentracija grikių grūduose sieke $486 \pm 238 \mu \mathrm{g} \mathrm{kg}{ }^{-1}$, tačiau pasitaikè mėginių, kurių koncentracijos varijavo nuo $240,0 \mu \mathrm{g} \mathrm{kg}^{-1} \mathrm{iki}$ $1010,2 \mu \mathrm{g} \mathrm{kg}^{-1}$. Pažymètina, kad visi tirti DON mėginiai viršijo kūdikių ir vaikų mitybai skirtų perdirbti grūdinių produktu $\left(200 \mu \mathrm{g} \mathrm{kg}^{-1}\right)$ leistinas koncentracijas, o $1010,2 \mathrm{~kg} \mathrm{~kg}^{-1}$ DON kiekis viršijo Europos komisijos reglamento (EB) Nr. 1881/2006 leidžiamas koncentracijas grūduose, skirtuose tiesiogiai vartoti žmonèms $\left(750 \mu \mathrm{g} \mathrm{kg}^{-1}\right)$.

ZEA buvo užteršti $25 \%$ tirtu mėginių, tačiau nustatytos koncentracijos sieke net $150 \mu \mathrm{g} \mathrm{kg}^{-1}$ (2 lentelè). Šie rezultatai keletą kartų viršijo Europos komisijos reglamento (EB) Nr. 1881/2006 
1 lentelè. Grikių grūdų užterštumas mikroskopiniais grybais 2011 m.

Table 1. Buckwheat grain contamination with fungi in 2011

\begin{tabular}{|c|c|c|}
\hline $\begin{array}{l}\text { Eksperimentas } \\
\text { Experiment }\end{array}$ & $\begin{array}{l}\text { Grūdų užterštumas } \\
\text { Contamination of } \\
\text { grain } \mathrm{Ksv}^{-1} \times 10^{4}\end{array}$ & $\begin{array}{l}\text { Dominuojančios grybų gentys } \\
\text { Dominant fungal genera }\end{array}$ \\
\hline $\begin{array}{l}\text { Po derliaus nuėmimo } \\
\text { After harvesting }\end{array}$ & $25,5 \pm 2,42$ & $\begin{array}{l}\text { Cladosporium spp., Colletotrichum spp., Alter- } \\
\text { naria spp., Penicillium spp., Mycelia sterilia, Fusari- } \\
\text { um spp. Acremonium spp., Botrytis spp. }\end{array}$ \\
\hline $\begin{array}{l}\text { Po } 7 \text { mènesiu sandèliavimo } \\
\text { After 7-month storage }\end{array}$ & $31,5 \pm 2,35$ & $\begin{array}{c}\text { Cladosporium spp., Alternaria spp., Penicillium spp., } \\
\text { Mycelia sterilia., Fusarium spp., Mucor spp., Rhizo- } \\
\text { pus spp., Aspergillus spp. }\end{array}$ \\
\hline
\end{tabular}

2 lentelè. $\mathbf{2 0 1 1}$ m. grikių grūdų užterštumas mikotoksinais

Table 2. Mycotoxin contamination in buckwheat grains in 2011

\begin{tabular}{|c|c|c|c|c|}
\hline \multirow{3}{*}{$\begin{array}{l}\text { Užterštumo lygis ir koncentracijos / Level of } \\
\text { contamination and concentrations }\end{array}$} & \multicolumn{2}{|c|}{$\begin{array}{l}\text { Po derliaus nuėmimo } \\
\text { After harvesting }\end{array}$} & \multicolumn{2}{|c|}{$\begin{array}{l}\text { Po } 7 \text { mènesių laikymo } \\
\text { After } 7 \text {-month storage }\end{array}$} \\
\hline & \multicolumn{4}{|c|}{ Mikotoksinai / Mycotoxin } \\
\hline & DON & ZEA & OCH A & AFL $B_{1}$ \\
\hline Ištirtų mėginių skaičius / Number of samples & 12 & 12 & 12 & 12 \\
\hline Mèginių užterštumas / Sample contamination, \% & 100 & 25 & 100 & 100 \\
\hline $\begin{array}{c}\text { Koncentracijuc vidurkis } \\
\text { Average concentrations of the samples, } \mu \mathrm{g} \mathrm{kg}^{-1}\end{array}$ & 469,7 & 24,4 & 1,55 & 1,62 \\
\hline Didžiausia vertè / Maximum value, $\mu \mathrm{g} \mathrm{kg}^{-1}$ & 1010,2 & 150,5 & 1,9 & 2,3 \\
\hline Mažiausia vertè / Minimum value, $\mu \mathrm{g} \mathrm{kg}{ }^{-1}$ & 240,0 & 0 & 1,2 & 1,0 \\
\hline Standartinè paklaida / Standard error, $\mu \mathrm{g} \mathrm{kg}{ }^{-1}$ & 204,38 & 51,92 & 0,23 & 0,49 \\
\hline Variacijos koeficientas / Variation coefficient, \% & 43,51 & 213,15 & 15,07 & 30,17 \\
\hline
\end{tabular}

kūdikiams ir vaikams leistinas ribas $\left(20 \mu \mathrm{g} \mathrm{kg}^{-1}\right)$ ir du kartus suaugusių žmonių sveikatai pavojingas ribas $\left(75 \mu \mathrm{g} \mathrm{kg}^{-1}\right)$.

AFL $B_{1}$ vidutinè koncentracija grikių grūduose nustatyta $1,6 \pm 0,5 \mu \mathrm{g} \mathrm{kg}^{-1}$ ir varijavo nuo $1,08 \pm 0,02 \mu \mathrm{g} \mathrm{kg}{ }^{-1}$ iki $2,3 \pm 0,2 \mu \mathrm{g} \mathrm{kg}^{-1}$, tai $10 \mathrm{ir}$ daugiau kartų viršijo kūdikiams ir vaikams leistinas koncentracijas $\left(0,1 \mu \mathrm{g} \mathrm{\textrm {kg } ^ { - 1 }}\right)$, o pusè méginių buvo artimi arba viršijo suaugusių žmonių tiesiogiai vartoti leistinas ribas $\left(2,0 \mu \mathrm{g} \mathrm{kg}^{-1}\right)$. AFL $B_{1}$ buvo užteršti visi tirti grikių mèginiai.

OCH A koncentracijos grikių grūduose buvo nedidelès, tačiau visi méginiai (100 \%) buvo užteršti šiuo mikotoksinu (2 lentelè).

1 pav. pateikti duomenys rodo, kad nevalytuose grikių grūduose mikotoksinų rizika didèja. Neišvalytuose grikių grūduose AFL $B_{1}$ koncentracijos padidejo beveik dvigubai, o OCH A - $22 \%$.

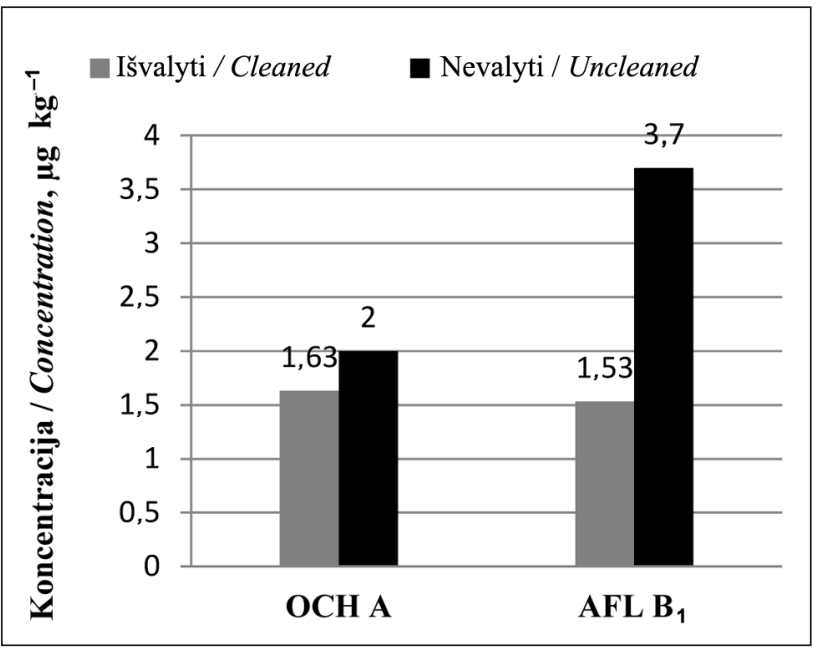

1 pav. AFL $B_{1}$ ir OCH A koncentracijų kitimas išvalytuose ir nevalytuose grikių grūduose 2011-2012 m.

Fig. 1. Variation of AFL $B_{1}$ and OCH A concentrations in cleaned and uncleaned buckwheat grain in 2011-2012 
Reikšminga, kad 2011 m. tirti grikių mėginiai buvo užteršti ne vienu, o keliais mikotoksinais. Mikotoksinų sudèties analizè atskleidè, kad $78 \%$ grikių mèginių buvo užteršti trimis toksinais - DON, AFL $B_{1}$ ir OCH A ir $22 \%$ - visais keturiais tirtais mikotoksinais (2 pav.). Šie tyrimai rodo, kad grikių, kaip ir miglinių javų grūdų, tyrimai mikotoksinų atžvilgiu yra aktualūs ir verti didesnio dèmesio, nes grikių grūduose privalomos tik AFL $\mathrm{B}_{1}$ analizès.

2012-2013 tyrimu metais didesnis dèmesys buvo kreipiamas ị grikių grūdų užterštumą Fusarium spp. genties grybais, nes $2011 \mathrm{~m}$. nustatytos didesnès DON, ZEA, T2/HT toksinų koncentracijos grikių grūduose. Nors $2011 \mathrm{~m}$. ant grikių grūdų

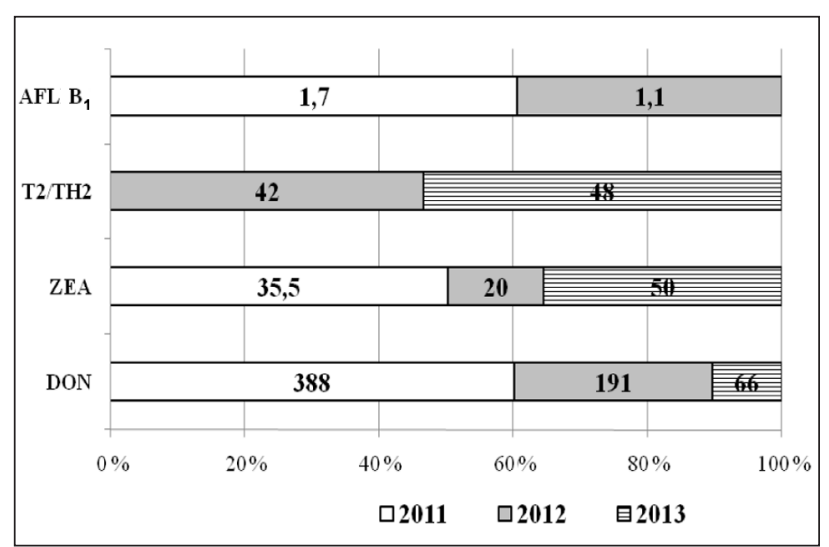

2 pav. Mikotoksinų kiekiai, artimi arba viršijantys EK reglamento Nr. 1881/2006 didžiausias leistinas koncentracijas ekologiškai augintuose grikių grūduose 2011$2013 \mathrm{~m}$

Fig. 2. Mycotoxin concentrations in buckwheat grain exceeding maximum mycotoxin concentrations allowable for organically produced buckwheat grain according to EC Regulation No. 1881/2006
Fusarium spp. infekcija nebuvo didelè (3 lentelè), tačiau vyraujančios Fusarium rūšys lèmè jų produkuojamų mikotoksinų koncentracijas (Pszczółkowska et al., 2011).

Rezultatai parodè, kad grikiai šiais mikroskopiniais grybais mažiausiai buvo užteršti $2011 \mathrm{~m}$. (11\%). Ivvertinus jų rūšinę sudètį, nustatyta, kad didžiausią dali sudare F. equiseti ( $6 \%)$, F. sporotrichioides $(\sim 4 \%)$ F. avenaceum, ir F. semitectum (1 \%). 2012 m. po derliaus nuèmimo užterštumas Fusarium grybais buvo apie 3 kartus didesnis (37\%), palyginti su $2011 \mathrm{~m}$. Didžiausią dalị sudaré $F$. avenaceum rūšies grybai - $38 \%$, F. sporotrichioides $-8 \%$ ir F. equiseti - 2,2\%.

2013 m. grikių derlius buvo gausiai užterštas Fusarium genties grybais, tačiau DON ir ZEA gaminančių rūšių (F. graminearum, F. culmorum) pasitaike pavieniai atvejai.

Tyrimo laikotarpiu gauti mikroskopinių grybu analizès rezultatai artimi A. Pszczółkowska ir kt. (2011) bei E. Krysińska-Traczyk ir kt. (2007) atliktiems tyrimams, kurie rodo, kad grikių grūdus daugiausia kolonizuoja Alternaria alternata rūšies, taip pat Mucor spp., Cladosporium spp., Botrytis spp., Penicilium spp. grybai.

Fusarium genties grybais buvo užteršta daugiau nei $20 \%$ bendro izoliatu kiekio, tačiau mikotoksinus produkuojančių grybų rasti tik pavieniai atvejai. Tiketina, kad mikroskopiniams grybams plisti palankias sąlygos sudare $2012-2013 \mathrm{~m}$. vasaros metu trumpi, bet gausiai lietingi periodai, be to, grikiu grūdų kokybei svarbus tinkamas žemès dirbimas ir piktžolių naikinimas iki sejjos. Anksčiau sudygusios ir sutankejjusios piktžolès laimi konkurencinę kovą prieš grikius, sulaiko drègmę dirvoje, todèl sudaro

3 lentelè. 2011-2013 m. derliaus grikių grūdų užterštumas Fusarium spp. grybais

Table 3. Fusarium spp. contamination in buckwheat grain harvested in 2011-2013

\begin{tabular}{|c|c|c|}
\hline $\begin{array}{c}\text { Metai } \\
\text { Year }\end{array}$ & $\begin{array}{l}\text { Mèginių užterštumas } \\
\text { Fusarium spp. grybais } \\
\text { Sample contamination by } \\
\text { Fusarium spp. fungi, \% }\end{array}$ & $\begin{array}{l}\text { Ant grikių sèklų aptiktos Fusarium rūšys } \\
\text { Fusarium species detected on buckwheat seeds }\end{array}$ \\
\hline 2011 & $11,0 \pm 6,3$ & $\begin{array}{c}\text { F. equiseti, F. sporotrichioides, F. avenaceum, F. poae, F. semitectum, } \\
\text { F. graminearum ir kt. Fusarium spp. }\end{array}$ \\
\hline 2012 & $37,0 \pm 29,7$ & $\begin{array}{l}\text { F. avenaceum, F. sporotrichioides, F. equiseti, F. oxysporum, F. poae ir } \\
\text { kt. Fusarium spp. }\end{array}$ \\
\hline 2013 & $56,5 \pm 12,0$ & $\begin{array}{l}\text { F. avenaceum, F. sporotrichioides, F. poae, F. graminearum ir kt. Fusa- } \\
\text { rium spp. }\end{array}$ \\
\hline
\end{tabular}


palankias sąlygas vystytis Fusarium genties ir kitiems mikroskopiniams grybams bei mikotoksinu sintezei (Zakarackas, 1999; Bernhoft et al., 2012).

Kadangi 2012 m. derliaus grikių grūdai buvo gausiau užteršti Fusarium spp. grybais nei 2011 m. (3 lentelè), analizei buvo pasirinkti DON, ZEA ir T-2/TH2 toksinai bei sandèliuotuose grūduose plitusio Aspergillus spp. sintetinamas AFL $\mathrm{B}_{1}$. Ivertinus mikotoksikologinę taršą, nustatyta, kad gautos koncentracijos buvo ženkliai mažesnès negu 2011 m. derliaus (4 lentele)). Nors DON ir ZEA kiekiai didžiausių leistinų koncentracijų neviršija, tačiau grikių grūdų užterštumas artimas ribinèms toksinèms normoms, tokių grūdų kūdikių ir vaikų mitybai naudoti nerekomenduojama. Kadangi tirtuose méginiuose viena iš vyraujančių rūšių buvo F. sporotrichioides, 2012 m. ištyrème T2/TH2 toksino koncentraciją, nes ši Fusarium rūšis yra viena iš minèto mikotoksino produkuotojų $(\mathrm{Pa}-$ terson, Lima, 2010). Tyrimai parodè, kad grikių mèginiai užteršti T2/TH2 toksinais. Nustatytos koncentracijos buvo nedidelès, tačiau jų aptikta visuose tirtuose méginiuose. Šio toksino didžiausia leistina koncentracija dar nèra reglamentuota, tačiau saugi rekomenduotina norma neturètų viršyti $100 \mu \mathrm{g} \mathrm{kg}^{-1}$ (Eriksen, Aleksander, 1998). Atlikus AFL $B_{1}$ tyrimus po 7 mènesių sandèliavimo, visuose tirtuose grikių mėginiuose aptikta šio mikotoksino pèdsakų $\left(0,9-1,5 \mu \mathrm{g} \mathrm{kg}^{-1}\right)$. Reikšminga, kad visuose 2012 m. derliaus grikiu grūduose aptikta visų keturių analizuotų mikotoksinų pèdsakų, tokia grikių grūdų maistinè vertė kelia grèsmę kūdikių ir vaikų sveikatai (EB Nr. 1881/2006).

Atlikti 2013 m. derliaus grikių grūdų DON, ZEA ir T2/TH2 tyrimai. Jie parode, kad, kaip ir 2012 m. méginiuose, nustatyta visų trijų mikotoksinų pédsakai (5 lentelè). Atliktos DON koncentracijos labai nedidelès, tačiau kai kuriuose

4 lentelè. $\mathbf{2 0 1 2}$ m. grikių grūdų užterštumas mikotoksinais

Table 4. Mycotoxin contamination in buckwheat grain samples in 2012

\begin{tabular}{|c|c|c|c|c|}
\hline \multirow{2}{*}{$\begin{array}{l}\text { Užterštumo lygis ir koncentracijos } \\
\text { Level of contamination and concentrations }\end{array}$} & \multicolumn{4}{|c|}{ Mikotoksinai / Mycotoxins } \\
\hline & DON & ZEA & T2/HT2 & AFL $B_{1} \times$ \\
\hline Ištirtų mėginių skaičius / Number of samples & 6 & 6 & 6 & 6 \\
\hline Mèginių užterštumas / Sample contamination, \% & 100 & 100 & 100 & 100 \\
\hline $\begin{array}{c}\text { Koncentraciju vidurkis } \\
\text { Average concentrations of the samples, } \mu \mathrm{g} \mathrm{kg}^{-1}\end{array}$ & 173,3 & 19,4 & 29,7 & 1,1 \\
\hline Didžiausia verté / Maximum value, $\mu \mathrm{g} \mathrm{kg}$ & 191,5 & 20,2 & 41,9 & 1,5 \\
\hline Mažiausia vertè / Minimum value, $\mu \mathrm{g} \mathrm{kg}^{-1}$ & 160,7 & 18,0 & 22,6 & 0,9 \\
\hline Standartine paklaida / Standard error, $\mu \mathrm{g} \mathrm{kg}^{-1}$ & 13,5 & 0,65 & 9,00 & 0,25 \\
\hline Variacijos koeficientas / Variation coefficient, $\%$ & 7,79 & 3,35 & 30,28 & 22,94 \\
\hline
\end{tabular}

* po 7 ménesių sandèliavimo / after 7-month storage

5 lentelè. $\mathbf{2 0 1 3}$ m. grikių grūdų užterštumas mikotoksinais po derliaus nuẻmimo

Table 5. Mycotoxins contamination of buckwheat grain after harvest in 2013

\begin{tabular}{|c|c|c|c|}
\hline \multirow{2}{*}{$\begin{array}{l}\text { Užterštumo lygis ir koncentracijos } \\
\text { Level of contamination and concentration }\end{array}$} & \multicolumn{3}{|c|}{ Mikotoksinai / Mycotoxins } \\
\hline & DON & ZEA & T2/HT2 \\
\hline Ištirtų mėginių skaičius / Number of samples & 6 & 6 & 6 \\
\hline Mèginių užterštumas / Sample contamination, \% & 100 & 100 & 100 \\
\hline Koncentraciju vidurkis / Average concentrations of the samples, $\mu \mathrm{g} \mathrm{kg}$ & 42,2 & 49,1 & 32,2 \\
\hline Didžiausia vertè / Maximum value, $\mu \mathrm{g} \mathrm{kg}^{-1}$ & 109,3 & 61,0 & 50,2 \\
\hline Mažiausia vertė / Minimum value, $\mu \mathrm{g} \mathrm{kg}{ }^{-1}$ & 24,0 & 29,1 & $<\mathrm{LOD}^{*}$ \\
\hline Standartinè paklaida / Standard error, $\mu \mathrm{g} \mathrm{kg}{ }^{-1}$ & 33,07 & 14,89 & 16,95 \\
\hline Variacijos koeficientas / Variation coefficient, \% & 78,36 & 30,36 & 52,68 \\
\hline
\end{tabular}

* nustatymo riba / limit of detection 
mèginiuose ZEA koncentracijos $\left(61,0 \mu \mathrm{g} \mathrm{kg}^{-1}\right)$ beveik du kartus didesnès negu rekomenduotinos normos kūdikių ir vaikų sveikatai (EB Nr. 1881/2006).

Ekologiškomis žemdirbystės sąlygomis išaugintuose grikių grūduose atliktos DON, ZEA, T2/ HT2 ir AFL $B_{1}$ analizès. Nustatyta, kad grikiai užteršti dviem ar daugiau toksinų, kurių koncentracijos buvo artimos ar viršijo Europos komisijos reglamento (EB) Nr. 1881/2006 leistinas arba rekomenduojamas vertes kūdikių ir vaikų mitybai skirtiems grūdiniams produktams (2 pav.).

Chromatografiniai DON tyrimai parodè, kad šiuo toksinu labiausiai užteršti $2011 \mathrm{~m}$. derliaus grikių grūdų méginiai (3 pav.). 2012 ir 2013 m. DON koncentracijos grikių grūduose buvo daugiau nei 50 \% bei nustatyta, kad 2011-2012 m. ekologiškai auginti grikių grūdai buvo labiau užteršti DON negu auginti ịprastai.

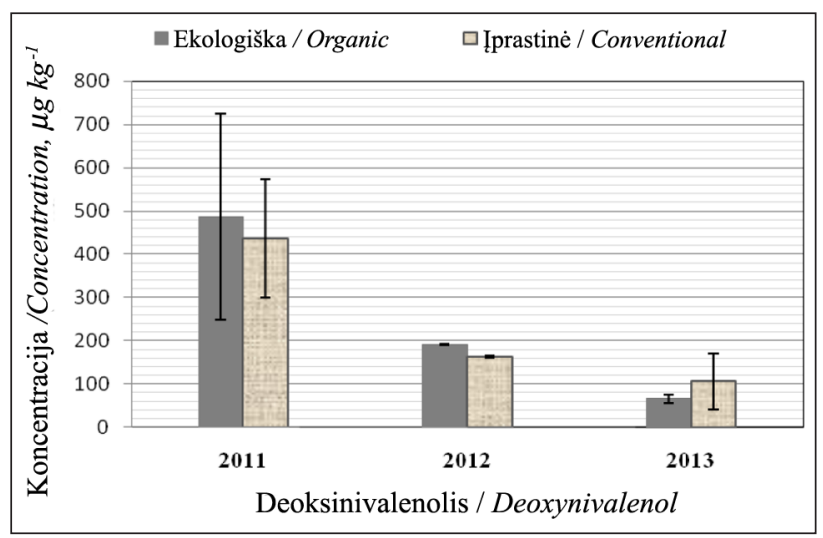

3 pav. DON koncentracijos $\left(\mu \mathrm{g} \mathrm{kg}{ }^{-1}\right)$ grikių grūduose, augintuose ekologiškomis ir iprastinemis žemdirbystès sąlygomis 2011-2013 m.

Fig. 3. DON concentrations $\left(\mu \mathrm{kg}^{-1}\right)$ in buckwheat grain from organic and conventional farms in 2011-2013

Mūsų atlikti eksperimentai didžiąja dalimi sutampa su kitų mokslininkų, dirbančių toje pačioje srityje, duomenimis. E. Krysińska-Traczyk (2007) tyrimai rodo, kad grikių grūdai užteršti 33,3\% DON ir $50 \%$ OCH A, tačiau ribinių verčių nustatyti kiekiai neviršijo. G. C. Llelewelyn ir kt. (1988) rezultatai rodo, kad 7 \% grikių lukštų buvo užteršti Aspergilus flavus ir nustatytos AFL $\mathrm{B}_{1}$ bei AFL $\mathrm{G}_{1}$ koncentracijos atitinkamai 13,8 ir 19,2 $\mu \mathrm{g} \mathrm{g}^{-1}$. Taip pat aptiktas T-2 toksinas, kurio koncentracija sieke $18,9 \mu \mathrm{g} \mathrm{g}^{-1}$. J. J. Matić ir kt. (2009) ištyrè 26 įvai- rių grūdų mėginius ir nustatè, kad grikių mėginyje DON ir OCH kiekis viršijo reglamentuotas EK normas, ir visi tirti méginiai buvo užteršti daugiau negu vienu toksinu.

Pastebèta tendencija, kad ekologiškai auginti javai (avižos, miežiai, kviečiai) mažiau užteršti mikotoksinais negu auginti ịprastai. Viena iš priežasčių, kad ant augintų ịprastai javų grūdų neidentifikuota mikotoksinus sintetinančių grybų rūšių (Bernhoft et al., 2010). I. Giménez ir kt. (2012) teigia, kad didesnes mikotoksinų koncentracijos ekologiškuose, palyginti su augintuose ịprastai, javuose lemia pasèlių žydèjimo metu užsitęsęs lietingas periodas (>100 mm), o E. Edesi ir kt. (2012) nustatè, kad ekologiški pasèliai labiau piktžolèti negu auginti íprastai. Tad tikètina, kad 2011-2012 m. eksperimento metu lietingi periodai sudare palankias sąlygas mikroskopiniams grybams plisti, o dèl didesnio piktžolètumo ekologiškuose grikių pasèliuose ilgiau susilaikiusi drègmè lèmè didesnes mikotoksinų koncentracijas. Kadangi mokslininkai plačiai nagrinèja mikotoksikologinę taršą ịvairių javų grūduose, bet mažai atlikta tyrimų apie ekologiškai ir ịprastai augintų grikių grūdų užterštumą mikotoksinais, tikslinga ir toliau tęsti šios srities tyrimus.

\section{IŠVADOS}

1. 2011-2013 m. grikių grūdai buvo pažeisti $F u$ sarium genties grybais, kurių užterštumas skirtingais tyrimų metais siekè $11-58,5 \%$. Ivvertinus rūšinę sudèti, didžiausią dali sudaré $F$. avenaceum, F. sporotrichioides, F. equiseti, F. poae, F. semitectum, F. graminearum ir kt. Fusarium spp. rūšiu sudètis skirtingais tyrimų metais, kaip ir analizuotų mikotoksinų koncentracijos, skyrèsi.

2. Po 7 ménesių sandèliavimo atliktos analizès parodè, kad atsirado grūdų, užterštų Mucor, Rhizopus, Aspergillus, padidejo užterštumas Penicillium genčiu grybais. Akivaizdu, kad šie grybai pateko iš sandèliavimo aplinkos, nes po derliaus nuemimo jų nebuvo nustatyta. Nevalytuose grikių grūduose $\mathrm{AFL} \mathrm{B}_{1}$ rizika padidèjo dvigubai, o $\mathrm{OCH}$ A $-22 \%$.

3. Trijų tyrimų metų duomenimis nustatyta, kad grikių, augintų ekologiškai ir iprastai, didžiausia mikotoksikologinè tarša buvo 2011 m.: $78 \%$ grikių méginių buvo užteršti trimis toksinais - DON, AFL $\mathrm{B}_{1}$ ir OCH A bei $22 \%$ méginiu 
keturiais toksinais - DON, AFL $\mathrm{B}_{1}, \mathrm{OCH} A$ ir ZEA. Daugeliu atvejų DON, ZEA ir AFL $B_{1}$ kiekiai viršijo Europos komisijos reglamento (EB) Nr. 1881/2006 reglamentuotas kūdikių ir vaikų mitybai skirtų perdirbti grūdinių produktų leidžiamas koncentracijas.

\section{PADE்KA}

Straipsnyje pateikti tyrimų rezultatai, gauti vykdant LMT projektą (sutarties Nr. SVE-04/2014) „Sveikų produktų gamybai aktualių augalų saugos ir kokybès gerinimas auginant ir perdirbant" pagal nacionalinę mokslo programą „Saugus ir sveikas maistas“.

Gauta 20140418

Priimta 20140626

\section{LITERATŪRA}

1. Amarowicz R., Fornal L. 1987. Characteristics of buckwheat grain mineral components and dietary fiber. Fagopyrum. Vol. 7. P. 3-6.

2. Bernhoft A., Torp M., Clasen P-E., Løes A. K., Kristoffersen A. B. 2012. Influence of agronomic and climatic factors on Fusarium infestation and mycotoxins contamination of cereals in Norway. Food Additives and Contamination. Vol. 29. P. 1129-1140.

3. Brindzová L., Mikulášová M., Takácsová M., Mošovská S., Opattová A. 2009. Evaluation of the mutagenicity and antimutagenicity of extracts from oat, buckwheat and wheat bran in the Salmonella / microsome assay. Journal of Food Composition and Analysis. Vol. 22. P. 87-90.

4. Čabarkapa I. S., Sedej I. J., Sakač M. B., Šarić L. Č., Plavšić D. V. 2008. Antimicrobial activity of buckwheat (Fagopyrum esculentums Moench) hulls extract. Food Processing, Quality and Safety. Vol. 4. P. 159-163.

5. Diaz D. E. 2005. The Mycotoxin Blue Book. Nottingham University Press. 349 p.

6. Edesi E., Järvan M., Adamson A., Lauringson E., Kuht J. 2012. Weed species diversity and community composition in conventional and organic farming: a five-year experiment. ZemdirbysteAgriculture. Vol. 99. No. 4. P. 339-346.

7. Eriksen G. S., Alexander J. 1998. Fusarium Toxins in Cereals - a Risk Assessment. TemaNord Report 502. Nordic Council of Ministers, Copenhagen. $115 \mathrm{p}$.

8. Europos Sajungos oficialusis leidinys L 364/5. 2006. Komisijos reglamentas (EB) Nr. 1881/2006.

9. Giménez I., Escobar J., Ferruz E., Loran S., Herrera M., Juan T., Herrera A., Arino A. 2012. The effect of weather and agronomic practice on mycotoxin in durum wheat. Journal of Life Sciences. Vol. 6. P. 513-517.

10. Juodeikienè G., Bašinskienè L. 2012. Grūdu laikymo, kokybes nustatymo ir apskaitos vadovas. Lietuvos grūdų perdirbèjų asociacija. 298 p.

11. Krysińska-Traczyk E., Perkowski J., Dutkiewicz J. 2007. Levels of fungi mycotoxins in the samples of grain and grain dust collected from five various cereals crops in Eastern Poland. Annals of Agricultural and Environmental Medicine. Vol. 14. P. 159-167.

12. Krkoškova B., Mrázova Z. 2005. Prophylactic components of buckwheat. Food Research International. Vol. 38. P. 561-568.

13. Leslie J. F., Summerell B. A. The Fusarium Laboratory Manual. 2006. Iowa. USA: Blackwell Publishing. 388 p.

14. Llewellyn G. C., Sherertz P. C., Armstrong C. W., Miller G. B., Reynolds J. D., Kimbrough T. D., Bean G. A., Hagler W. M., Haney C. A., Trempus C. S., O’Rear C. E., Dashek W. V. 1988. Mycotoxigenic isolates and toxin production on buckwheat and rice hulls used as bedding materials. Journal of Industrial Microbiology. Vol. 3. P. 351356.

15. LST EN 15891:2010. Maisto produktai. Deoksinivalenolio nustatymas grūduose, ju produktuose ir kūdikiams bei mažiems vaikams skirtuose grūdiniuose maisto produktuose. Efektyviosios skysčiu chromatografijos metodas, taikant gryninima imuninio giminiškumo kolonèlëje ir ultravioletinị aptikima. Vilnius: Lietuvos standartizacijos departamentas, 2010.

16. LST EN ISO 7218:2007. Maisto ir pašaru mikrobiologija. Mikrobiologiniu tyrimu bendrieji reikalavimai ir rekomendacijos (tapatus ISO 7218:2007). Vilnius: Lietuvos standartizacijos departamentas, 2008.

17. Lugauskas A. Mikotoksinų kaupimosi maiste dèsningumai ir prevencinių saugos priemoniu paieška. 2006. Maisto chemija ir technologija. Nr. 2. P. 16-27.

18. Mathur S. B., Kongsdal O. 2003. Common Laboratory Seed Health Testing Methods for Detecting Fungi. Copenhagen. 425 p.

19. Matić J. J., Mastiloviã J., Čabarkapa I. S., Mandiã A. I. Mycotoxins as a risk in the grain food. 2009. Zbornik Matice srpske za prirodne nauke / Proc. Nat. Sci, Matica Srpska Novi Sad. No. 117. P. 79-86.

20. Mošovská S., Bírošová L. 2012. Antimycotic and antifungal activities of amaranth and buckwheat extracts. Asian Journal of Plant Sciences. Vol. 3. P. 160-162.

21. Nelson P. E., Toussoun T. A., Marasas W. F. O. 1983. Fusarium Species: An Illustrated Manual for Identification. London. 193 p.

22. Paterson R. M., Lima N. 2010. Toxicology of mycotoxins. Toxicology. Vol. 2. P. 31-59. 
23. Pczczółkowska A., Fordónski G., Olszewski J., Okorski A. 2011. The effect of fungicide treatment on the productivity and health of buckwheat seeds (Fagopyrum esculentum Moench). Polish Journal of Natural Sciences. Vol. 26. No. 1. P. 14-26.

24. Satton D., Fotergill A., Rimaldi M. 2001. Opredelitel patogennykh i uslovno patogennykh gribov. Moskva. $451 \mathrm{s.}$

25. Shapira R. 2004. Control of mycotoxins in storage and techniques for their decontamination. In: Mycotoxins in Food - Detection and Control. Cambridge, England. P. 190-223.

26. Tarakanovas P., Raudonius S. 2003. Agronominiu tyrimu duomenu statistine analize taikant kompiuterines programas ANOVA, STAT, SPLIT-PLOT iš paketo SELEKCIJA ir IRRISTAT. Akademija. P. 57.

27. Vojtí̌̌ková P., Kmentová K., Kubáň V., Kráčmar S. 2012. Chemical composition of buckwheat plant (Fagopyrum esculentum) and selected buckwheat product. Journal of Microbiology, Biotechnology and Food Sciences. Vol. 1. P. 1011-1019.

28. Zakarackas R. 1999. Grikiai. Lietuvos žemdirbystès institutas, Perlojos bandymų stotis. 30 p.

29. Žemés ūkio informavimo ir kaimo verslo centras. Informacija apie $2013 \mathrm{~m}$. Lietuvoje deklaruotas žemès ūkio naudmenas, miškus ir kitus plotus [žiūrèta 2014-03-06]. Prieiga per interneta: https://www. vic.lt/uploads/file/Pasel2013-galutinis\%283\%29. pdf
Ilona Kerienè, Audronė Mankevičienè, Rūta Česnulevičienė, Eugenija Bakšienè

\section{BUCKWHEAT GRAIN CONTAMINATION WITH MICROSCOPIC FUNGI AND MYCOTOXINS}

Summary

Buckwheat grain contamination with microscopic fungi and mycotoxins was investigated at the Lithuanian Research Centre for Agriculture and Forestry (LRCAF) during 2011-2013. The aim of the research was to determine microscopic fungi and mycotoxin contamination in buckwheat grain harvested in 2011-2013. Test grain samples were collected from the fields of organically and conventionally produced buckwheat of the LRCAF Voke Branch and the Perloja Experimental Station. Mycotoxins in grain were detected by immunoenzyme (ELISA) and high performance liquid chromatography (HPLC) methods. The test showed that the grains were infested with the fungi of Fusarium genus and the grain contamination level ranged from $11-58.5 \%$ in different years. Analysis of the species composition indicated $F$. avenaceum, F. sporotrichioides, F. equiseti, F. poae, F. semitectum, $F$. graminearum to account for the largest share. Fusarium spp. composition differed between experimental years, likewise the concentrations of the assayed mycotoxins.

Analyses done after 7 months of storage showed the fungus of Mucor, Rhizopus, Aspergillus, Penicillium to be present on the stored grain. This suggests that these fungi were present in the storage environment since no presence of them was detected shortly after harvesting. In uncleaned grain, the risk of $A F L B_{1}$ doubled and that of $\mathrm{OCH} A$ increased by $22 \%$. The greatest mycotoxicological contamination on buckwheat grain was identified in 2011, when $78 \%$ of buckwheat samples were co-contaminated with three toxins - DON, AFL B and $\mathrm{OCH} A$, and $22 \%$ of samples were co-contaminated with four toxins - DON, AFL $B_{1}$, OCH A and ZEA.

Key words: buckwheat, mycotoxins, contamination, microscopic fungi 